\title{
Tumor Metabolism and Neuroimaging: Proton Magnetic Resonance Spectroscopy in Cerebral Glioma
}

\author{
Brandon Muncan* and Liliana Nussbaum \\ Stony Brook University, USA \\ Submission: July 17, 2017; Published: July 28, 2017 \\ *Corresponding author: Brandon Muncan, Stony Brook University, New York, USA, Tel: 9175863385; Email: brandon.muncan@stonybrook.edu
}

\begin{abstract}
The advent of nuclear neuroimaging techniques has vastly changed neurobiology and neuroscience from a bench-research oriented practice to a clinical sub discipline with diagnostic and therapeutic implications. In particular, magnetic resonance spectroscopy (MR spectroscopy) began as a tool in understanding cellular metabolism in tissues of the prostate gland, kidney, and brain, and has since evolved into a useful diagnostic and prognostic tool in clinical neurology [1]. In this review, the use of proton MR spectroscopy in the diagnosis and grading of glioma is summarized.
\end{abstract}

Keywords: Glioma; Magnetic resonance spectroscopy; Neuroimaging; Metabolism

Abbreviations: MRS: Magnetic Resonance Spectroscopy; NMR: Nuclear Magnetic Resonance; PMRS/HMRS: Proton Magnetic Resonance Spectroscopy.

\section{Introduction}

Magnetic resonance spectroscopy, abbreviated MRS is a biochemical technique used to identify the concentration of various cellular metabolites in tissue. The origins of MRS lie within the physical sub discipline of nuclear magnetic resonance spectroscopy (NMR), which was used as early as the 1950's for identification of nuclear magnetic moments of nuclei. Since the introduction of NMR to clinical medicine in the form of magnetic resonance imaging (MRI), many improvements have been made to quantify metabolite concentrations rather than just to provide anatomical images. In particular, proton magnetic resonance spectroscopy (proton MRS or 1HMRS) was developed as an accurate and highly sensitive neuroimaging technique to assess metabolic changes in brain tumors and other degenerative central nervous system diseases.

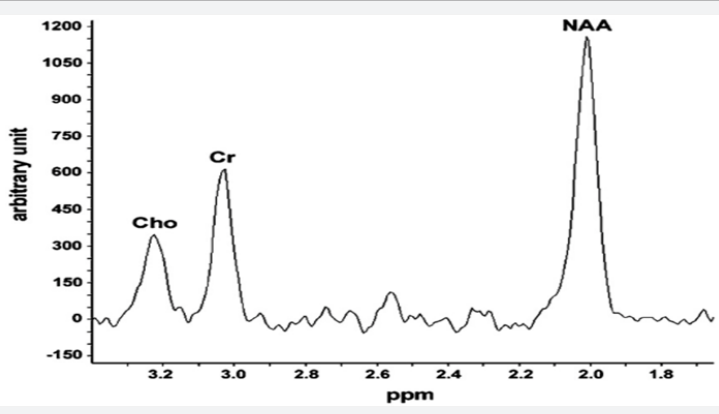

Figure 1: Normal Occipital Lobe Proton MRS spectrum [2].
Proton MRS technology is based on the chemical shift of hydrogen atoms in targeted tissues, according to the Larmor equation $[1,2] . f=\gamma \mathrm{HB}$. where the resonance of the hydrogen nuclei, $f$, is equal to the product of the gyro magnetic ratio constant of the species (in this case $1 \mathrm{H}$ ), $\gamma \mathrm{H}$, and the external magnetic field applied by the MRS apparatus, B0. Interactions between the hydrogen atoms and surrounding particles produces the chemical shift: a change in magnetic field, thereby emanating a frequency within the MRS spectrum. Frequencies can be measured in parts-per-million, and are shown on the $\mathrm{x}$-axis of an MRS graphic plot. The vertical, $\mathrm{y}$-axis of an MRS plot is the relative magnetic field strength, or amplitude generated by a particular metabolite, See Figure 1. Metabolite with normal spectra peaks are listed in Table 1.

Table 1: MRS metabolites and corresponding peak values [1].

\begin{tabular}{|c|c|}
\hline Metabolite & Role and Peak size \\
\hline Choline (Cho) & Cellular proliferation marker; peaks at \\
$3.22 \mathrm{ppm}$
\end{tabular}




\section{Global Journal of Intellectual \& Developmental Disabilities}

\begin{tabular}{|c|c|}
\hline Alanine (Ala) & $\begin{array}{l}\text { Role in tri carboxylic acid cycle; peaks at } \\
1.48 \mathrm{ppm} \text {. }\end{array}$ \\
\hline Glx Complex & $\begin{array}{l}\text { Excitatory neurotransmission; peaks at } \\
2.25 \mathrm{ppm} .\end{array}$ \\
\hline Lipids (Lip) & $\begin{array}{c}\text { Marker of cellular membrane destruction and } \\
\text { necrosis; peaks at } 1.30 \mathrm{ppm} .\end{array}$ \\
\hline Myoinositol (Myo) & $\begin{array}{l}\text { Glial cell proliferation marker; peaks at } \\
\text { 3.56ppm. }\end{array}$ \\
\hline
\end{tabular}

Along with anatomical imaging provided by MRI, proton MRS has been shown to have value in the characterization, preoperative grading, and prognosis of cerebral gliomas [3]. Whereas conventional imaging is especially adept at identifying tumor location, size, and hemorrhage, proton MRS can aid in further evaluating the cellular metabolism of the tumoral microenvironment and thereby present insight into the invasiveness of such neoplasm. The biochemistry and molecular physiology of the tumor and peritumoral areas can be evaluated for extent of micro necrosis and gross cell differentiation, and can be useful in cancer grading and prognostic outlook calculations $[3,4]$.

It is agreed on, and accepted in the literature that the hallmark of many cerebral neoplasms have the following conglomerate of metabolite levels on proton MRS imaging [2-9]:

i. $\quad \mathrm{N}$-acetylaspartate (NAA) decrease, secondary to loss of axonal viability. ii. Choline (Cho) increase, secondary to neo plastic cell proliferation.

iii. Lipid (Lip) increase, secondary to peritumoral necrosis (if lesion is of a higher grade).In differentiating between low and high-grade gliomas metabolites such as choline, Glx complex and myoinositol can be used [1,3-5]:

i. Choline (Cho) peak heights are generally proportional to aggressiveness of a glioma.

ii. High myoinositol peak height generally corresponds to higher-grade dysplastic or anaplastic glioma.

iii. High Glx complex (glutamine, glutamate, and GABA) peak height corresponds to a higher-grade glioma.

\section{Discussion and Conclusion}

In addition to the grading of a cerebral glioma, proton MRS is a useful tool in delineating tumoral margins non-invasively. In areas around a given neoplasm, higher proton MRS peaks of choline and Glx-complex indicate positive margins, information which is crucial for neurosurgeons in the operating room. Overall, the adjuvant employment of proton MRS in glioma evaluation, along with conventional neuroimaging and neuropathology increases physician awareness, and improves subsequent quality of care. Case-examples of proton MRS use in glioma are shown in Figures 2 \& 3 .
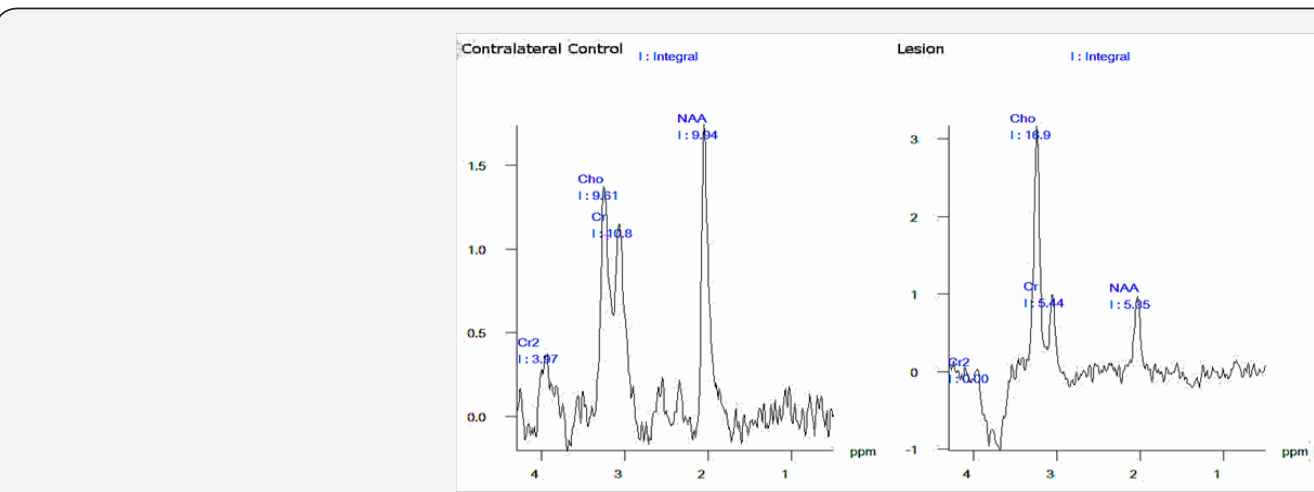

Figure 2: Metabolic comparison between normal brain tissue and low-grade glioma. Choline and creatinine peaks are elevated, $\mathrm{N}$-acetylaspartate peak is depressed.

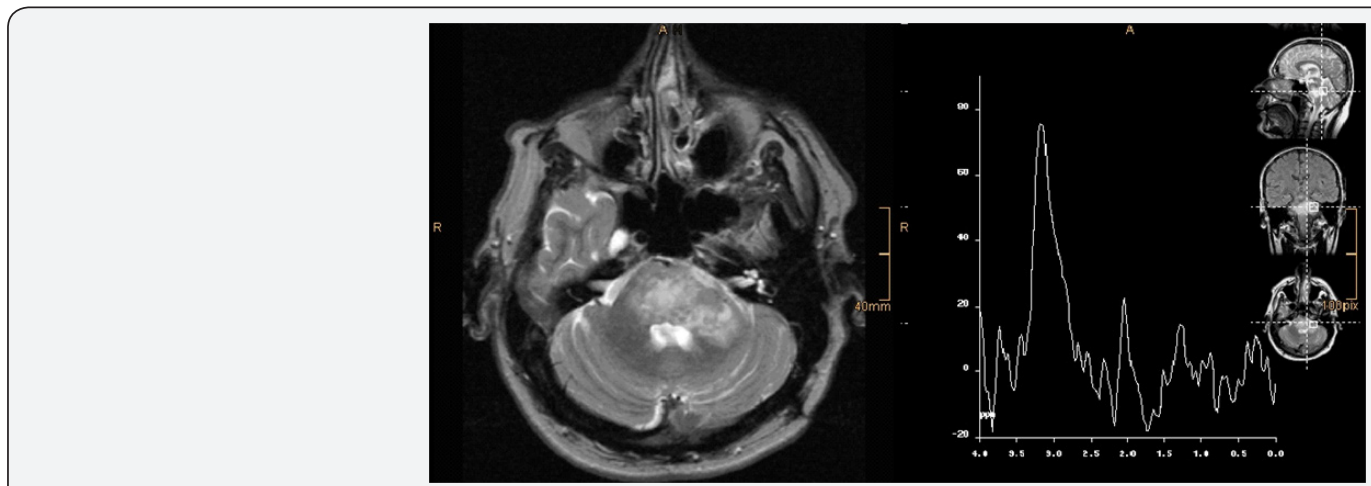

Figure 3: Single-voxel proton MRS of a patient with a brainstem glioma. MRS shows elevated choline and creatinine peaks as well as a depressed $\mathrm{N}$-acetylaspartate peak. Lactate and lipids are also present indicating a higher-grade lesion. 


\section{References}

1. Jackman LM, Sternhell S (2013) Application of Nuclear Magnetic Resonance Spectroscopy in Organic Chemistry: International Series in Organic Chemistry Elsevier.

2. Bertholdo D, Watcharakorn A, Castillo M (2013) Brain proton magnetic resonance spectroscopy: introduction and overview. Neuroimaging Clin N Am 23(3): 359-380.

3. García-Figueiras R, Baleato-González S, Padhani AR, Oleaga L, Vilanova JC, et al. (2016) Proton magnetic resonance spectroscopy in oncology: the fingerprints of cancer? Diagn Interv Radiol 22(1): 75-89.

4. Fan G (2006) Magnetic resonance spectroscopy and gliomas Comments And Controversies. Cancer Imaging 6(1): 113-115.

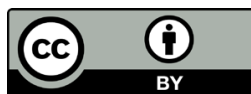

This work is licensed under Creative Commons Attribution 4.0 Licens

DOI: 10.19080/GJIDD.2017.02.555589
5. Preul MC, Caramanos Z, Collins DL, Villemure JG, Leblanc R, et al. (1996) Accurate non invasive diagnosis of human brain tumors by using proton magnetic resonance spectroscopy. Nat Med 2(3): 323325 .

6. https://commons.wikimedia.org/w/index.php?curid=794142

7. https://commons.wikimedia.org/w/index.php?curid=19210677

8. Öz G, Alger JR, Barker PB, Bartha R, Bizzi A, et al. (2014) Clinical proton MR spectroscopy in central nervous system disorders. Radiology 270(3): 658-679.

9. Boucard CC, Hoogduin JM, Van Der Grond J, Cornelissen FW (2007) Occipital proton magnetic resonance spectroscopy $\left({ }^{1} \mathrm{H}-\mathrm{MRS}\right)$ reveals normal metabolite concentrations in retinal visual field defects. PLoS One 2(2): e222.

\section{Your next submission with Juniper Publishers will reach you the below assets}

- Quality Editorial service

- Swift Peer Review

- Reprints availability

- E-prints Service

- Manuscript Podcast for convenient understanding

- Global attainment for your research

- Manuscript accessibility in different formats ( Pdf, E-pub, Full Text, Audio)

- Unceasing customer service

Track the below URL for one-step submission https://juniperpublishers.com/online-submission.php 